\title{
DEVELOPMENT OF DRIBBLING BASIC TECHNIQUE SKILL OF STUDENTS OF PSTS TABING PADANG FOOTBALL SCHOOL
}

\author{
Emral $^{1}$, James A.P. Tangkudung ${ }^{2}$ \\ ${ }^{1}$ Universitas Negeri Padang, Indonesia \\ ${ }^{2}$ Universitas Negeri Jakarta, Indonesia \\ 1emral_abus@yahoo.co.id
}

\begin{abstract}
The objective of this research is to create dribbling learning models and to experiment dribbling training models of playing football for students of Football School (FBS) of PSTS Tabing Padang. This research was conducted at the FBS using the football experts and the students as the subjects. The research conducted was development model of Borg and Gall. The validation data of the experts were collected through field notes and questionnaires, analyzed by descriptive analysis technique. The dribbling basic technique skill of football was analyzed by using t-test. The research findings are as follows: (1) football dribbling basic technique skill which were developed based on the training principles and training methodology, starting from the simple one and ended by game situation, (2) the training model is very effective to be used in the process of training, (3) it was empirically proved that the model was effective.
\end{abstract}

Keywords: training model; dribbling; playing football.

Football game's development continue to be accepted and loved by the any levels of society and has been included in the school curriculum. Football game is a sport that many people do (mass), interesting, easy to do, fun and cheap. Through the activities of football games, we can develop organic, neoromuscular, intellectual and emotional capabilities thoroughly.

To be able to play football well, students or players should be able to perform the proper basic technique movements. In a sense that in accordance with the rules of the game and the development of technical quality of the game that refer to the level of basic techniques mastery. Basic techniques mastery of football game should have been a serious concern since early time for school teachers, coaches and football trainers in football clubs especially in Football School (FBS). The basic techniques are fundamental and must be mastered by all players in order to play football skillfully that is based on the ability of multilateral movements.

Training aspects that need to be developed in youngsters especially are the correct basic movement technique skills with good basic physical abilities. Therefore, every coach is required to understand training the steps and aspects of the training, hence they will know when and how big the portion is of practice for multilateral and specialization. By mastering the techniques of playing football, players will be able to play the ball in any circumstances in any games, thus it will ease the players in setting tactics, and in the end they will be able to create good cooperation, in groups and teams to achieve victory.

The basic techniques in playing football are movements without a ball and movements with a ball which are needed to play football. According to Soekatamsi 
(1997), football skill is the application of basic techniques in playing football. Basic movement activities in playing football such as the basic techniques mastery that are divided into several basic techniques, namely: kicking, holding the ball, dribbling the ball, feinting, heading the ball, tackling the ball, throwing -in, goalkeeping. The basic movement techniques will develop to be more complex movements (Arma Abdoelah: 1985). Complexity of movements which is developed will be more variaous along with the maximum achievements that want to be achieved.

The technique skill factors and the the basic technique mastery of playing football are very influential on the ability of playing football. Arma Abdoelah (1985) said Dribbling is one of the essential basic element in playing football. Dribbling is a skill in dribbling balls by running using parts of feet to push the ball so the ball continuous to roll on the ground. The good dribbling ball skill is very helpful in attacking and creating goals.

To be able to dribble quickly, the players must have a good ability in mastering and controlling the ball, changing the speed, and also the right feinting. If it is not supported by those factors, then dribbling can not be done quickly so the ball will be grabbed easily by the opponents. Therefore, doing dribbling should be adjusted with the situation and the condition in the game. Regular and structured or programmed trainings by using parts of legs are better to improve the ball dribbling abiliity.

Ball dribbling is a technique of an attempt to move a ball from one point to another at the time the game is in progress. According Witarsa (1984) the aims of dribbling the ball are to: (1) pass the opponent, (2) look for opportunities to give the ball to friend properly, (3) hold the ball and keep it in control and save the ball if there is no possibility or opportunity to pass immediately to a friend. Along with that, Soekatamsi (1997) stated ball dribbling technique principals are; (1) A ball is in the control of a player, the ball is always close to legs, body. The players are between the ball and the opponent hence the ball will not be tackled by the opponents easily, the ball is always in control, (2) in front of the players there are empty areas, free from the opponents, (3) the ball is dribbled with the right and left feet, each footstep push the ball forward, (4) the heads are held high, and (5) the body lean forward, the free hand movements as the regular running time.

Furthermore, Joseph Luxbacher (1998) affirmed that the ball dribbling technique is someone's way used to move the ball from one point to another, to try to prevent the opponents having a chance to tackle the ball. Components that support the success of good ball dribbling, namely sudden speed and direction changes, body and leg feinting movements and tight ball control. Weil Coerver (1985) also stated we need to pay attention to the feet in order to move as fast as and as flexible as possible in touching the ball with a few quick touches that can transfer the ball to the other foot, the same movement is repeated with the opposite direction. To support these techniques, ball control must be utilized optimally. It is recommended to use the dribbling technique to refrain passing the opponents in our own one-third of the defense area which is close our own goal area. If we lose the ball easily, the opponent will score a goal.

Observing the quote above, it can be concluded that ball dribbling is someone's ability to be able to move a ball from one place to another by using the foot's touch and roll the ball continuously on the ground with various speeds, in order to keep the ball away from the opponents' attack, and to pass the opponents, as well as to look 
for an opportunity to provide feedback to a friend or crossing balls to be able to score a goal.

In the implementation of dribbling, football players must control the ball well in narrow areas despite the pressure from the opponents. The ball should always be touched at any protects the ball from the opponent or passing the opponent along with changes in circumstances that occur. On the other hand, the ball must be maintained in a controlled until there is an opportunity to pass the ball to a friend or to release a shot to score a goal.

Based on the experts' explanation above, what it means by the result of basic technique training of dribbling in football is a change in behavior as a result of a training process. The training result mentioned is what the players gain in psychomotor after dribbling basic techniques training which include: the first touch when they receive the ball, running technique while dribbling the ball, body technique while dribbling the ball, and foot touching technique on the ball.

Regular and programmed training from an early age will make the basic techniques of dribbling better. Training does not only include dribbling, but also the other football techniques, as well as tactical and phisical exercises in it. Coaches are required to be able to create a training model program in which there is a fundamental exercise, game related and game situation (AFC, 1999). Forms of training program contains technical training, technical skills, and playing which are performed sequentially every training session. This training model program can be used by coaches to train a group of students of the age 13-14.

\section{METHOD}

The general aim of this research is focused on developing research models and development (R \& D) (Borg, Walter R. and Gall, 1983). Specifically, namely: 1) Producing a ball dribbling basic skills training model product of SSB KU students with the average of 13-14 years old. 2) Experimenting dribbling skill training model of playing football product of SSB KU students with the average of 13-14 years old.

This research was conducted in SSB PSTS Tabing Padang, in the academic year 2012 / 2013. The method used is descriptive method with the following design:

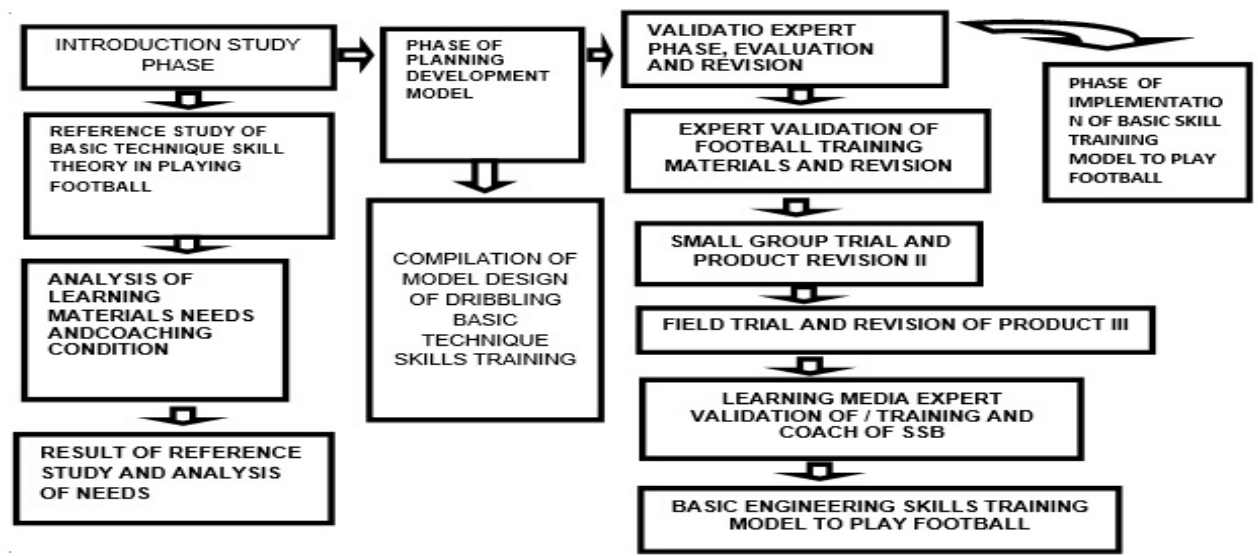

Figure 1. Development Steps of Basic Technique Skill Training Model Playing of Football (Source: Compiled Alone) 
The target population is all students of SSB PSTS Tabing Padang amounting 150 students. While the accessible population is Tabing Padang SSB PSTS students with the age of 13-14 years who are active in doing training amounting 80 students. Samples were taken by simple random sampling from the accessible population who have the same characteristics which consist of groups, namely the experimental group of 40 students and a controlled group of 40 students.

Instruments used are in the form of test and non test. The tests were performed before and after treatment using the True Experimental Design (Pretest - Posttest Only Control Design). The treatment was given in the form of dribbling training model which was held three times a week; on Wednesday, Friday afternoon and Sunday morning with time duration of 90 minutes.

Data of dribbling basic techniques include: the first touch when receiving the ball, running technique while dribbling the ball, body technique while dribbling the ball, and foot technique while touching the ball. The four indicators developed into three points diskriptor with assessment scores range from three to one (3-1). Score $3=$ three diskriptors are correct, (if movement such as the above is done correctly). Score 2 = only two diskriptors are correct (if movement such as the above is done with one mistake. Score 1 = only one correct diskriptor (if movement such as the above is done with two mistakes).

\section{RESULTS}

Validation result data processing of football training expert on development design of dribbling basic technique skill training model of playing football is $84.89 \%$ in average.

Table1. Data Validation Result of Football Training Experts $n=3$ with the instrument amounting 64 questions.

\begin{tabular}{clcccc}
\hline No. & Expert & $\begin{array}{c}\text { Minimum } \\
\text { Score }\end{array}$ & $\begin{array}{c}\text { Maximum } \\
\text { Score }\end{array}$ & $\begin{array}{c}\text { Result } \\
\text { Score }\end{array}$ & Percentage \\
\hline 1. & Football Training Expert 1 & 64 & 256 & 226 & 88.28 \\
2. & Football Training Expert 2 & 64 & 256 & 220 & 85.94 \\
3. & Football Training Expert 3 & 64 & 256 & 206 & 80.47 \\
\hline Average & & & & 84.89 \\
\hline
\end{tabular}

While the advices from the football training experts are as follows: (1) the input from three football training experts; it was found that the training formation on dribbling basic technique skills model in playing football is that we need to pay attention to the number of groups with one ball to have the same opportunity. (2) The three football training experts provide inputs to make the game more fun so that the training will be full of joy and fun.

Football training/learning media expert validation result data in the form of dribbling basic technique skill training model development design in playing football of SBS students; it is found that the average of football training/learning media experts validation result is $87.96 \%$. 
Table 2. Learning/Training Media Expert Validation Results $n=3$ with 36 Questions

\begin{tabular}{llcccc}
\hline No & Expert & $\begin{array}{c}\text { Minimum } \\
\text { Score }\end{array}$ & $\begin{array}{c}\text { Maximum } \\
\text { Score }\end{array}$ & $\begin{array}{c}\text { Result } \\
\text { Score }\end{array}$ & Precentage \\
\hline 1. & Football Training Media & 36 & 144 & 120 & 83.33 \\
& Expert 1 & & 144 & 133 & 92.36 \\
2. & $\begin{array}{l}\text { Football Training Media } \\
\quad \text { Expert 2 }\end{array}$ & 36 & 144 & 127 & 88.19 \\
3. & $\begin{array}{l}\text { Football Training Media } \\
\text { Expert 3 }\end{array}$ & 36 & & & 87.96 \\
\hline Average & & &
\end{tabular}

Advice from learning/training media experts found that in basic technique skill training model video of playing football there is focus placement that that is not suitable when there are things that need to be displayed, as well as the placement of the caption should be placed under the clear sign.

Validation resultsdata of SSB coach on the design of dribbling basic technique skills learning model development in playing football of SSB students; it is found that the average validation result of the SSB football coach is $85.16 \%$.

Table 3. Form Data Validation Results Coach SSB n = 3 with 64 Questions

\begin{tabular}{llcccc}
\hline \multirow{2}{*}{ No. } & Experts & $\begin{array}{c}\text { Minimum } \\
\text { Score }\end{array}$ & $\begin{array}{c}\text { Maximum } \\
\text { Score }\end{array}$ & $\begin{array}{c}\text { Result } \\
\text { Score }\end{array}$ & Percentage \\
\hline 1. & SSB Football Coach 1 & 64 & 256 & 223 & 87.11 \\
2. & SSB Football Coach 2 & 64 & 256 & 206 & 80.47 \\
3. & SSB Football Coach 3 & 64 & 256 & 225 & 87.89 \\
\hline Average & & & 85.16 \\
\hline
\end{tabular}

While the advice of the three coaches of SSB PSTS Tabing Padang, that the development of related game $3 \mathrm{v} 1$ should be $4 \mathrm{v}$ not $5 \mathrm{v} 2$ in order to be seen as diamond shape in the play.

The overall data processing of test results of small group (12) and field trials (30) has an average of $88.04 \%$.

Table 4. Test Results Data of Small Groups (12) and Field Trial Group 30 with 64 Questions Instruments

\begin{tabular}{clcccc}
\hline No. & Expert & $\begin{array}{c}\text { Minimum } \\
\text { Score }\end{array}$ & $\begin{array}{c}\text { Maximal } \\
\text { Score }\end{array}$ & $\begin{array}{c}\text { Result } \\
\text { Score }\end{array}$ & Precentage \\
\hline 1. & Small group Trial $(\mathrm{n}=12)$ & 768 & 3072 & 2717 & 88.44 \\
2. & Field Trial Group 30 & 1920 & 7680 & 6731 & 87.64 \\
\hline Average & & & & 88.04 \\
\hline
\end{tabular}

The advices on the development of basic technique skill training models in playing football at a small trial group (12) are: (1) Giving longer duration of the game form on the basic technique skill training of football needs to be carried out, because it is very useful to enhance the players' ability and increase motivation, (2 ) add repetition / frequency of training on any training material so the technique skills of students become better.

The observation result of a small group trial test shows filed note is obtained that while dribbling each player should have the ball in order to touch more not too long in waiting their turn among the other players, to avoid boredom.

While the advice on the development of dribbling basic technique skill training model in playing football at field trial of their 30 group; the also wanted more games 
because it has become a habit. Based on observations in the field trial there are some field notes obtained, initially while performing the training of their fundamentals they were a little bit bored, but after entering the games related stage, fun games as well as the stage of the game situation which they do very enthusiasticly.

The appropriateness of the training model of the developed basic technique skill in playing football can be known through the analysis of obtained validation result data. Based on data collecting result through questionnaires of football training expert, learning / training media expert, SSB coach , and SSB students both in small trial group (12) and in field trial group (30).

After small trial group with $n=12$, the second phase revision done on the component product of development of dribbling basic technique skill training model in playing football, then followed by field trials with $n=30$, continued by the revision of stage three. To know the product excellence of the development of basic technique skill learning model in playing football, then implementation process is carried out, using a True Experimental Design study design (Pretest - Posttest Only Control Design) Sugiyono (2009).

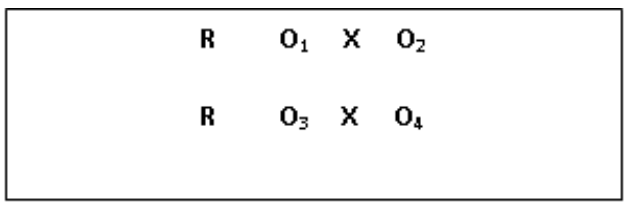

In this design, there are two groups which were selected randomly, then they were given a pretest to determine the initial state is there any difference between the experimental group and the control group. Pre-test result is good if the value of the experimental is significant. The effect of treatment is (O2 - O1) - (O4 - O3).

The main characteristic of True Experimental is that, the samples used for experiments as well as the controlled group are taken randomly from a particular population. In order to test the excellent of the application of basic technique skill training model in playing football at SBS' students used the "t-test" technique.

Table 5. Summary of Effectiveness of Test Results of Dribbling Basic Technique Skill Training in Playing Football using "t-test"

\begin{tabular}{cccccc}
\hline $\begin{array}{c}\text { Type of Basic } \\
\text { Technique Skill }\end{array}$ & unit & $\mathbf{X}_{\mathbf{1}}$ & $\mathbf{X}_{\mathbf{2}}$ & $\mathbf{t}_{\text {thitung }}$ & $\mathbf{t}_{\text {tabel }}$ \\
\hline Dribbling & Figure & 9,77 & 8,62 & 9,263 & 2,023 \\
\hline Explanation
\end{tabular}

Explanation:

$\mathrm{X}_{1}=$ the average value of the experimental group

$\mathrm{X}_{2}=$ the average value of the conventional group

The calculation of excellence test steps of application of dribbling basic technique skills training model in playing football for SSB students using the "t-test" technique. With Dribbling results are: $X_{1}=9.77, X_{2}=8.62$, $t_{\text {hitung }}=9.263$, and $t_{\text {tabel }}=2.023$. the level of sign $(\alpha)$ of 0.000 . Level sign $(\alpha)$ counted less than $\alpha=0.025$. It means that Ho is refused and $\mathrm{H}_{1}$ is accepted, thus the hypothesis stated that there are the differences in students' skills of dribbling the ball between the groups of students who treated by the basic technique skill training model of playing football with a 
group of students who were given conventional treatment training proved to be very significant.

\section{DISCUSSION}

Based on the test results of small trial group and large trial group or field trial also effectiveness test of the model that has been explained, it was found that the product of the dribbling basic skill training model of playing football that is developed in this study is considered to meet the requirements and have the excellences to be socialised and applied in football trainings KU 13 - 14 years.

Based on the data that has been collected from various experts; football coaches, learning / training media, as well as data from the SSB coach while trial a small group $n=12$ and field trial $n=30$ for students of SSB, there are some parts of the product that need to be revised.

Furthermore, with regard to the revision of stage I, stage II, stage III, the supporting and inhibiting factors, as well as the strengths and the weaknesses of the development product of dribbling basic technique skill training model of playing football for students of SSB.

Revision of stage I is done after obtaining inputs and advices from football coach experts. Inputs and advice as well as the received data served as the basis for revising the following stage in small group trial $n=12$.

The validation results of three football coach experts stated that all aspects of product development of dribbling basic technique skill training model of playing football for SBS' students have met the standard and very proper to use. However, in order to enhance the draft for a revised recommended among others: (1) the training formation of basic technique skill model in playing football need to pay attention to the number of groups become larger and each player with one ball to get the same opportunities and do a lot of repetition of motion; (2) in the game related training, image or color of strikers and defenders should be differentiated in order to facilitate the understanding of training materials; (3) adding a fun game after funadamental training or after game related so the training will be enjoyable and fun.

Revision of stage II is implemented after obtaining the advice and input from the SSB' students who followed small group trial $n=12$. Advice, input and data obtained serve as the basis for the stage III revision of the development of dribbling basic techniques of skill training model of playing football for SBS' students.

The trial result of a small group $n=12$ turns product development of dribbling basic techniques of skill training model of playing football for SBS' students have met the standards and very decent to be used; in other words, there's no aspect that needs to be revised. The revision of this second stage include: (1) the form of the game (play) in training of dribbling ball basic technique skills need to be added, in order to improve the ability and motivation, (2) adding the repetition / frequency of training on each training material so that students technical skills become better, (3) while dribbling each player should have the ball in order to touch the ball more and not too long to wait, as it will cause boredom.

The revision in phase III or the revision of the final product after getting advices and inputs from field trials $n=30$. Data obtained from field trials $n=30$ is used as a 
basis of last stage revision of product development of dribbling basic techniques skill learning model of playing football for SSB' students.

The results of field trial $n=30$ indicates that the product development of dribbling basic techniques skill learning model of playing football for SSB' students does not need to be revised anymore, because all aspects shown have meet the standards and very proper to use. The special note of the observation on field trial, among others, initially when performing the training on their fundamental it was a little bit boring, but after entering the stage of games related, fun games as well as the stage of the game situation they are very enthusiastic to do them.

\section{CONCLUSION}

The result of this research can be concluded that (1) a dribbling basic technique skill training model is generally arranged based on the principles and training methodology of simple training begins with training techniques, in fundamental, continued to game related and fun game, ended with a game situation, (2) Development of dribbling basic technique skill training model has excellent model product, and (3) The test results of dribbling basic technique skills in playing soccer of experimental group showed an average number of posttest result was higher than the controlled group (conventional).

Thus, it can be stated that the dribbling basic technique skill training model in playing football has excellence to be used to improve the performance of dribbling basic technique skills of playing football for students of SSB PSTS Padang.

\section{REFERENCES}

Abdoelah, Arma. (1985). Olahraga untuk Pelatih Pembina dan Penggemar Bandung: Penerbit Pionir Jaya.

Borg, Walter R. and Gall, Meredith D. (1983). Education Research: An Introduction, $4^{\text {th }}$ Edition. New York: Longman Inc.

Coerver, Weil. (1985). Sepakbola: Program Pembinaan Pemain Ideal (Jakarta: PT. Gramedia.

Emral. (2005). Sepakbola (Buku Ajar). Padang: FPOK UNP Padang.

Hasantoso, Abi. (2010). Buku Putih Reformasi Sepakbola Indonesia. Jakarta.

Koger, Robert. (2005). Latihan Dasar Andal Sepakbola Remaja Latihan dan Keterampilan Andal untuk Pertandingan Dasar yang Lebih baik. Klaten, Indonesia: SMKK.

Luxbacher, Joseph. (1998). Sepakbola dan Teknik Bermain Jakarta: PT. Rajagrafindo Persada. 
Soekatamsi. (1997). Permainan Bola Besar, Sepak Bola, Jakarta: Departemen Pendidikan dan kebudayaan, Dirjen Dikdasmen.

Sugiyono. (2009). Statistik untuk Penelitian Bandung: Alfabeta.

(2009). Metode Penelitian Pendidikan, pendekatan Kuantitatif, Kualitatif, dan $R$ \& D. Bandung: Alfabeta.

Sudjana. (2002). Metoda Statistika. Bandung: Tarsito.

Witarsa, Aang. (1984). Taktik Sepakbola. Jakarta: PSSI. 